\title{
UROCHLOA GRASS GROWTH AS A FUNCTION OF NITROGEN AND PHOSPHORUS FERTILIZATION
}

\author{
Maurício Luiz de Mello Vieira LEITE ${ }^{1}$ \\ Leandro Ricardo Rodrigues de LUCENA ${ }^{1}$ \\ Raul Caco Alves BEZERRA ${ }^{1}$ \\ Mirna Clarissa Rodrigues de ALMEIDA ${ }^{1}$ \\ Vicente José Laamon Pinto SIMÕES ${ }^{1}$
}

- ABSTRACT: The urochloa grass (Urochloa mosambicensis) is a perennial grass, C4 plant, with a high photosynthetic rate and $\mathrm{CO}_{2}$ fixation, persistent to water deficit, adapted to a wide diversity of soils and hot climate regions. Thus, the objective was to evaluate the urochloa grass growth and define the best models to estimate plant height as a function of nitrogen and phosphate fertilization. The experimental design was completely randomized, in the $2 \times 2$ factorial design (presence and absence of nitrogen $\times$ presence and absence of phosphorus), with four replications. Was used a dose of nitrogen and phosphorus equivalent to $100 \mathrm{~kg}^{-h^{-1}}$ of $\mathrm{N}$ and $150 \mathrm{~kg} . \mathrm{ha}^{-1}$ of $\mathrm{P}_{2} \mathrm{O}_{5}$, respectively. The following models were used: linear, power, gamma and logistic to estimate plant height as a function of the following explanatory variables: days after planting, nitrogen and phosphorus doses. The criteria used to determine the best model(s) were as follows: higher adjusted coefficient of determination, lower Akaike information criterion, lower sum of square of residuals and high Willmott index. The plant height in the absence of nitrogen and phosphorus and when applied $100 \mathrm{~kg} \cdot \mathrm{ha}^{-1}$ of $\mathrm{N}$ and $150 \mathrm{~kg} \cdot \mathrm{ha}^{-1}$ of $\mathrm{P}_{2} \mathrm{O}_{5}$ was estimated more accurately by the Gamma model with high power of explanation. The adoption of the Gamma model allows to estimate the $U$. mosambicensis plant height, in a non-destructive manner, with high precision, speed and low cost, depending of age plant and nitrogen and phosphate fertilization.

- KEYWORDS: Gamma model, plant height, Urochloa mosambicensis.

\section{Introduction}

Urochloa grass (Urochloa mosambicensis) is a perennial grass originating of the African continent, $\mathrm{C} 4$ plant, with a high photosynthetic rate and $\mathrm{CO}_{2}$ fixation, persistent to water deficit, adapted to regions with a minimum mean annual rainfall of $500 \mathrm{~mm}$ and a wide diversity of soils (LEITE et al., 2017).

The Brazilian soils, for the most part, contain low levels of phosphorus, one of the elements that most limits the productivity of forages. Phosphorus has a direct influence on

\footnotetext{
${ }^{1}$ Universidade Federal Rural de Pernambuco - UFRPE, Campus Serra Talhada, Av. Gregório Ferraz Nogueira, CEP: 56909-535, Serra Talhada, PE, Brasil. E-mail: nopalea21@yahoo.com.br; leandroricardo_est@yahoo.com.br; raulcacoalvesbezerra@hotmail.com; mirna-clarissa@hotmail.com; laamoneng.agro@gmail.com
} 
root system growth and tillering of forage grasses (BEZERRA et al., 2017). Thus, in order to obtain sustainable crops and high forage yields in these soils, it becomes necessary and essential phosphorus fertilization, as well as nitrogen fertilization, which plays an important role in plant morphogenesis, promoting increase in the metabolism and rates of enzymatic reactions (BEZERRA et al., 2017). Nitrogen is the mineral element that plants require in larger quantities, under conditions of disability, nitrogen is the main limiting factor to plant growth and can significantly affect forage grasses productivity (MARTINS et al., 2008; MARTUSCELLO et al., 2015).

The fertilization plays an important role in soil fertility and grasses mineral nutrition, especially in relation to nitrogen and phosphorus. Research on increasing nitrogen and phosphorus doses emphasizes a positive influence on the obtained forage yield (MENEZES et al., 2018). However, the recommended applications are highly variable owing to the particularities of edaphoclimatic conditions under which each study was carried out (FARINELLI and LEMOS, 2012).

Adjustment of growth curves is an important tool for the understanding of the growth dynamics of the plant and its phenological stages (LUCENA et al., 2016). A growth curve is a sequence of measures (weight, length, height, etc.), evaluated repeatedly over time. Growth curves generate useful information such as: adequate crop management, period of higher plant growth, more suitable season for fertilization and pest control (MANGUEIRA et al., 2016).

In the last decades the growth curves in forage plants have been studied as reported in the growth studies in Urochloa spp. (IKEDA et al., 2013; MATA et al., 2011), in Cynodon (PEREIRA et al., 2012), in millet (ALMEIDA et al., 2017), among others. Recent studies have evaluated the agronomic characteristics of Urochloa mosambicensis, using nitrogen and phosphate fertilization (BEZERRA et al., 2017; 2019), cutting height management (SÁ JÚNIOR et al., 2018) and leaf area (LEITE et al., 2017; LUCENA et al., 2018).

The main growth characteristics of grasses are modified by nitrogen fertilization and plant height at harvest time, with effects on pasture productivity (PEREIRA et al., 2012). Although there is information regarding the agronomic characteristics of the urochloa grass, no growth curve of this grass was detected in the literature. In this sense, the objective was to define the best models for estimating the U. mosambicensis plant height submitted to nitrogen and phosphate fertilization.

\section{Material and methods}

Research was carried from September 2018 to January 2019 at site experimental of the Federal Rural University of Pernambuco (Serra Talhada County Campus, PE, Brazil), located at $07^{\circ} 57^{\prime} 01^{\prime \prime} \mathrm{S}, 38^{\circ} 17^{\prime} 53^{\prime \prime} \mathrm{E}$, at an elevation of $523 \mathrm{~m}$. According to Köppen, region climate classification is $\mathrm{BSwh}$. Annual average rainfall, air temperature and relative humidity are $632.2 \mathrm{~mm}, 26^{\circ} \mathrm{C}$ and $60 \%$, respectively (LEITE et al., 2019).

Local soil is Cambisol Eutrophic, and samples for analysis were collected from the first $20 \mathrm{~cm}$, then homogenized and passed through a $2.0 \mathrm{~mm}$ sieve. Subsequently, about $10.0 \mathrm{~kg}$ of this soil was packed in plastic vase with a volume of $14.42 \mathrm{dm}^{3}$, drilled in the bottom to facilitate the drainage of irrigation water and with a layer of $2.0 \mathrm{~cm}$ of gravel. The chemical and physical characteristics of this soil are: $\mathrm{pH}$ (water) $=7.20$; $\mathrm{P}$ (extractor 
Mehlich I $)=40 \mathrm{mg} \mathrm{dm}{ }^{-3} ; \mathrm{K}^{+}=0.45 ; \mathrm{Ca}^{2+}=5.3 ; \mathrm{Mg}^{2+}=1.1 ; \mathrm{Na}^{+}=0.06 ; \mathrm{Al}^{3+}=0.0 ; \mathrm{H}^{+}=$ 1.23; $\mathrm{SB}=6.91 ; \mathrm{CTC}=8.14\left(\mathrm{cmolc} \mathrm{dm}^{-3}\right)$ and $\mathrm{V}=84.89 \%$, sand $=72.2 \%$; silt $=17.2 \%$; clay $=10.5 \%$ and organic matter $=6.24 \mathrm{~g} \mathrm{~kg}^{-1}$.

Initially, two urochloa grass (Urochloa mosambicensis) tillers were transplanted by vase. In order to avoid water stress condition, in the first 30 days, all plants were maintained in field capacity condition, based on the gravimetric method, using a precision balance of $20.0 \mathrm{~g}$. The water content in the vase was controlled daily by the weight of the pot + soil + water set, replace the volume of water consumed (evapotranspiration) by the soil-plant system, according to Bezerra et al. (2019).

The experimental design was completely randomized, in the $2 \times 2$ factorial design (presence and absence of nitrogen $\mathrm{x}$ presence and absence of phosphorus), with four replications, totaling 16 experimental units. The nitrogen and phosphorus sources used were ammonium sulphate with $20 \% \mathrm{~N}$ and the single superphosphate with $18 \%$ water soluble P2O5, respectively. Was used a dose of nitrogen equivalent to $100 \mathrm{~kg} \cdot \mathrm{ha}^{-1}$ of $\mathrm{N}$ and a dose of phosphorus equivalent to $150 \mathrm{~kg} \cdot \mathrm{ha}^{-1}$ of $\mathrm{P}_{2} \mathrm{O}_{5}$. Nitrogen and phosphorus were applied on the roof, immediately after the cut of uniformity.

At 30 days after planting (DAP), with the full development of the seedlings, all the plants were submitted to the uniformity cut, at $10 \mathrm{~cm}$ above the soil surface, with the use of pruning shears and millimeter ruler. To evaluate the growth of the urochloa grass, a tiller was marked in each of the experimental plots. Then, five evaluations were performed of the urochloa grass plant height, every seven days after the first harvest, in each treatment. This process was performed for four consecutive cycles, totaling 20 plant height assessments. The plant height was measured with a millimeter ruler, considering the vertical distance from the plant base to the average curvature of the last fully expanded leaf, upper horizon of leaves in the canopy.

To choose the fittest model to predict urochloa grass plant height $(\mathrm{H})$ in function of the days after cut (DAC), regression studies were performed using the linear, power, gamma and logistic models (Table 1). The linear, power and logistic models with normal distribution, assuming that the response of dependent variable is in the range $(-\infty, \infty)$, and gamma models with gamma distribution, assuming that the response of dependent variable is in the range $(0, \infty)$ (Table 1$)$.

Table 1 - Regression models to explaining Urochloa mosambicensis plant height $(\mathrm{H})$ in relation the explanatory variable days after cut (DAC)

\begin{tabular}{ll}
\hline Models & \multicolumn{1}{c}{ Plant height equation } \\
\hline Linear & $\mathrm{H}_{\mathrm{i}}=\beta_{0}+\beta_{1} \mathrm{DAC}_{\mathrm{i}}+\varepsilon_{\mathrm{i}}$ \\
Power & $\mathrm{H}_{\mathrm{i}}=\beta_{0} \mathrm{DAC}_{\mathrm{i}}^{\beta_{1}} \varepsilon_{\mathrm{i}}$ \\
Gamma & $\mathrm{H}_{\mathrm{i}}=\left(\beta_{0}+\beta_{1} \mathrm{DAC} \mathrm{C}_{\mathrm{i}}+\varepsilon_{\mathrm{i}}\right)^{2}$ \\
Logistic & $\mathrm{H}_{\mathrm{i}}=\frac{\mathrm{w}}{1+\exp ^{\left(\beta_{0}+\beta_{1} \mathrm{DAC}\right)}+\varepsilon_{\mathrm{i}}}$
\end{tabular}

where, $\mathrm{H}_{\mathrm{i}}$ the $\mathrm{i}$-th $U$. mosambicensis plant height; $\mathrm{DAC} \mathrm{C}_{\mathrm{i}}$ the $\mathrm{i}$-th days after cut and $\varepsilon_{\mathrm{i}}$ the $\mathrm{i}$-th error interrelated the $U$. mosambicensis plant height, with $\varepsilon_{\mathrm{i}}$ exhibited normal distribution of mean 0 and variance constant $\sigma^{2}>0$ to the linear, power and logistic model and gamma distribution of parameters $\alpha$ and $\beta$ to gamma models. The w, $\beta_{0}$ and $\beta_{1}$ are parameters related to the model.

The following parameters were used to compare the models with the plant height, and from this assumption was choice the best model using as criteria: higher Coefficient 
of determination of the fitted model $\left(R_{a j u}^{2}\right)$, lower Akaike's Information Criterion (AIC), lower Sum of Square of Residuals (SSR) and higher Willmott index $(d)$.

The adjusted coefficient of model determination as presented by Santos et al. (2018) is expressed by:

$$
R_{a j u}^{2}=R^{2}-\frac{p-1}{n-p}\left(1-R^{2}\right)
$$

where, $0 \leq R_{a j u}^{2} \leq 1$ and $R^{2}=\frac{\text { SSReg }}{\text { SST }}$.

The Akaike information criteria (AIC), as defined by Akaike (1974), is given by:

$$
A I C=-2 \ln L(x / \hat{\theta})+2(p)
$$

The sum of square of the residuals (SSR) is the square sum of difference between the values observed and predicted by the models, where the lowest value contributes to the choice of the best equation. Define SSR for this study by the following expression:

$$
\operatorname{SSR}=\sum_{i=1}^{n}\left(Y_{i}-\hat{Y}_{i}\right)^{2}
$$

The d index defined by Willmott (1981) is given by

$$
d=1-\frac{\sum_{i=1}^{n}\left(\hat{Y}_{i}-Y_{i}\right)^{2}}{\sum_{i=1}^{n}\left(\left|\hat{Y}_{i}-\bar{Y}\right|+\mid Y_{i}-\bar{Y}\right)^{2}}
$$

where, $L(x / \hat{\theta})$ is the maximum likelihood function, defined as the production of density function, $n$ is the number of observations and $\mathrm{p}$ is the number of model parameters; $\widehat{Y}_{i}$ the values of the i-th $U$. mosambicensis plant height after model adjustment; $\bar{Y}$ is the mean of the values of the $U$. mosambicensis plant height $\left(Y_{i}\right)$.

The validation of the model that best explains the growth of U. mosambicensis was performed through the diagnostic analysis of the residues, where the studied residues were evaluated in relation to the fitted values, leverage points and influential (SILVA et al., 2019), lastly verified simulated envelopes method for residuals (LISKA et al., 2015).

The generalized hat matrix $(H)$ is given by:

$$
H=\widehat{W}^{1 / 2} X\left(X^{\prime} \widehat{W} X\right)^{-1} X^{\prime} \widehat{W}^{1 / 2}
$$

and

$$
\operatorname{rank}(H)=\sum_{i=1}^{n} h_{i i}=p
$$


where, $h_{i i}$ are the diagonal elements of matrix $H, \widehat{\mathrm{W}}$ is weight matrix. Assume that any observation that exceeds twice the average $\left(h_{i i}>2 p / n\right.$ or $\left.>3 p / n\right)$ is remote enough from the rest of the data to be considered a leverage point (SILVA et al., 2019).

Studentized residuals is defined by:

$$
r_{i}=\frac{e_{i}}{\sqrt{\frac{S S R}{n-p}\left(1-h_{i i}\right)}}
$$

where, $e_{i}$ is the residue of the $\mathrm{i}$-th observation of the model (difference between the observed value and the fitted by the model).

To detect a point of influence we use Cook's distance, defined by:

$$
D_{i}=\frac{r_{i}^{2}}{p} \frac{h_{i i}}{\left(1-h_{i i}\right)}
$$

if $\mathrm{D}_{\mathrm{i}}>2 \sqrt{\frac{\mathrm{p}}{\mathrm{n}}}$, we say that the point is influential (SILVA et al., 2019).

All results were obtained with the support of the $\mathrm{R}$ for windows software (R CORE TEAM, 2021). The parameters of the non-linear model were estimated by the Gauss Newton method modified using the command "nls", for the other models the parameters were estimated by maximum likelihood.

\section{Results and discussion}

The behavior of the $U$. mosambicensis plant height in the absence of nitrogen and phosphorus was best estimated by Gamma model, since it presented greater power of explanation $\left(R_{a j u}^{2}=99.2 \%\right)$ and Willmott index $(d=0.998)$ and smaller sum of squares of residuals (SSR=16.67) when compared to linear, power and logistic models, while the Akaike information criterion presented best performance for the power model (AIC = 1.31), as we can see in Table 2.

U. mosambicensis plant height in the absence of nitrogen fertilization and with application of $150 \mathrm{~kg} \cdot \mathrm{ha}^{-1}$ of phosphorus was best estimated by the Gamma model, the same presented high power of explanation $\left(R_{a j u}^{2}=99.7 \%\right)$ and Willmott index $(\mathrm{d}=0.999)$ and the smaller sum of squares of residuals $(\mathrm{SSR}=7.66)$ when compared to linear, power and logistic models (Table 2). The Akaike information criterion for the Gamma model presented the third best performance between the four models evaluated.

Gamma model was the most efficient to estimate the behavior of $U$. mosambicensis plant height with $100 \mathrm{~kg} \cdot \mathrm{ha}^{-1}$ of nitrogen and in the absence of phosphorus. Model presented higher power of explanation $\left(R_{a j u}^{2}=98.80 \%\right)$ and Willmott index $(d=0.997)$ and smaller sum of squares of residuals $(\mathrm{SSR}=31.24)$ when compared to linear, power and logistic models (Table 2). Power and logistic models presented the lowest AIC, while the Gamma model presented the third best performance of the AIC.

The model that best explains the behavior of U. mosambicensis plant height when fertilized with $100 \mathrm{~kg} \mathrm{ha}^{-1}$ of nitrogen and $150 \mathrm{~kg} \mathrm{ha}^{-1}$ of phosphorus is the Gamma, the 
same presented greater explanatory power $\left(R_{a j u}^{2}=99.1 \%\right)$, lower SSR (24.04) and higher Willmott index $(d=0.998)$, when compared to linear, power and logistic models (Table 2). Just as we three previous scenarios the Gamma model presented the third best performance for the AIC.

Table 2 - Estimates of parameters and criteria of adequacy of the models of Urochloa mosambicensis plant height $(\mathrm{H})$ in function of days after cut (DAC) and nitrogen and phosphorus of fertilization

\begin{tabular}{|c|c|c|c|c|c|}
\hline \multirow[b]{2}{*}{ Models } & \multirow{2}{*}{ Equations for plant height } & \multicolumn{4}{|c|}{ Criteria of adequacy of the model } \\
\hline & & $\mathrm{R}_{\mathrm{aju}}^{2}$ & SSR & AIC & $\mathrm{d}$ \\
\hline \multicolumn{6}{|c|}{ without fertilization } \\
\hline Linear & $\mathrm{H}=1.95 \mathrm{DAC}$ & 0.972 & 60.98 & 30.69 & 0.992 \\
\hline Power & $\mathrm{H}=\mathrm{DAC}^{1.21}$ & 0.972 & 60.49 & -1.31 & 0.994 \\
\hline Gamma & $\mathrm{H}=\left(\begin{array}{c}2.59+0.17 \mathrm{DAC})^{2} \\
73.75\end{array}\right.$ & 0.992 & 16.67 & 22.72 & 0.998 \\
\hline Logistic & $\mathrm{H}=\frac{}{1+\exp ^{(2.17-0.106 \mathrm{DAC})}}$ & 0.989 & 33.14 & 6.71 & 0.995 \\
\hline \multicolumn{6}{|c|}{ without nitrogen and with 150 kg.ha ${ }^{-1}$ of phosphorus } \\
\hline Linear & $\mathrm{H}=2.078 \mathrm{DAC}$ & 0.986 & 33.15 & 27.65 & 0.996 \\
\hline Power & $\mathrm{H}=\mathrm{DAC}^{1.24}$ & 0.963 & 85.95 & 0.74 & 0.992 \\
\hline Gamma & $\begin{array}{c}\mathrm{H}=(2.80+0.17 \mathrm{DAC})^{2} \\
75.10\end{array}$ & 0.997 & 7.66 & 19.41 & 0.999 \\
\hline Logistic & $\mathrm{H}=\overline{1+\exp ^{(2.28-0.123 \mathrm{DAC})}}$ & 0.991 & 19.30 & 1.55 & 0.998 \\
\hline \multicolumn{6}{|c|}{ with $100 \mathrm{~kg} \cdot \mathrm{ha}^{-1}$ of nitrogen and without phosphorus } \\
\hline Linear & $\mathrm{H}=2.19 \mathrm{DAC}$ & 0.979 & 51.22 & 29.82 & 0.995 \\
\hline Power & $\mathrm{H}=\mathrm{DAC}^{1.26}$ & 0.932 & 168.36 & 3.60 & 0.986 \\
\hline Gamma & $\begin{array}{c}H=(3.06+0.166 \mathrm{DAC})^{2} \\
77.80\end{array}$ & 0.988 & 31.24 & 28.18 & 0.997 \\
\hline Logistic & $\mathrm{H}=\overline{1+\exp ^{(2.23-0.125 \mathrm{DAC})}}$ & 0.984 & 40.79 & 4.56 & 0.996 \\
\hline \multicolumn{6}{|c|}{ with $100 \mathrm{~kg} \cdot \mathrm{ha}^{-1}$ of nitrogen and $150 \mathrm{~kg} \cdot \mathrm{ha}^{-1}$ of phosphorus } \\
\hline Linear & $\mathrm{H}=2.30 \mathrm{DAC}$ & 0.982 & 45.56 & 29.23 & 0.996 \\
\hline Power & $\mathrm{H}=\mathrm{DAC}^{1.28}$ & 0.898 & 263.05 & 4.34 & 0.980 \\
\hline Gamma & $\begin{array}{c}H=(3.25+0.166 \mathrm{DAC})^{2} \\
81.19\end{array}$ & 0.991 & 24.04 & 28.83 & 0.998 \\
\hline Logistic & $\mathrm{H}=\overline{1+\exp ^{(2.15-0.123 \mathrm{DAC})}}$ & 0.984 & 89.23 & 4.18 & 0.996 \\
\hline
\end{tabular}

Khan and Hussain (2004) evaluated the structural modifications in the buffelgrass (Cenchrus ciliaris L.) in response to five levels of nitrogen fertilization (10, 20, 30, 40 and $50 \mathrm{~kg}$ of $\mathrm{N} \cdot \mathrm{ha}^{-1}$ ) and concluded that higher nitrogen rates provided higher plant height. Cecato et al. (2001) verified that the regrowth vigor was higher in plants fertilized with nitrogen, which demonstrates the interaction between nitrogen and reserve carbohydrates 
in the sap circulating grass, elements that are mobilized after cutting or grazing, for the synthesis of tissue and protoplasmic content, implying a higher recovery speed after cutting or grazing.

Ikeda et al. (2013) fitted the quadratic polynomial model to explain the Urochloa spp. plant height with regular precision. Bezerra et al. (2019) fitted the linear regression model with $96.16 \%$ accuracy to explain the growth of $U$. mosambicensis as a function of nitrogen and phosphorus fertilization. Almeida et al. (2017) using the linear model with explanatory power of $90.56 \%$ to estimate the Pennisetum glaucum plant height.

With Gamma model presented the best results in all scenarios of nitrogen and phosphorus fertilization, it was decided to introduce beyond the variable age of the plant after each harvest or cut (DAC) the nitrogen and phosphorus levels as explanatory variable in the general model, to increase the accuracy of the Gamma model. The new Gamma model presented explanatory power of $99.2 \%$, sum of squares of residuals 79.61 , Akaike information criterion of 94.68 and Willmott index of 0.998 , indicating a good fit of the model.

The model fitted to explain the behavior of $U$. mosambicensis plant height showed values of height very close to the observed values (Figure 1), and defined by the following expression:

$$
H=(2.61+0.168 D A C+0.004 N+0.0014 P)^{2}
$$

where, for each increment of one day in the plant age after cut, an mean increase of 2.6 $\mathrm{cm}$ in plant height, with each increment of $1 \mathrm{~kg}^{-h^{-1}}$ of nitrogen applied is expected on mean an increase of $0.07 \mathrm{~cm}$ in plant height, while each increment of $1 \mathrm{~kg} \cdot \mathrm{ha}^{-1}$ of applied phosphorus is expected on mean an increase of $0.03 \mathrm{~cm}$ in plant height.

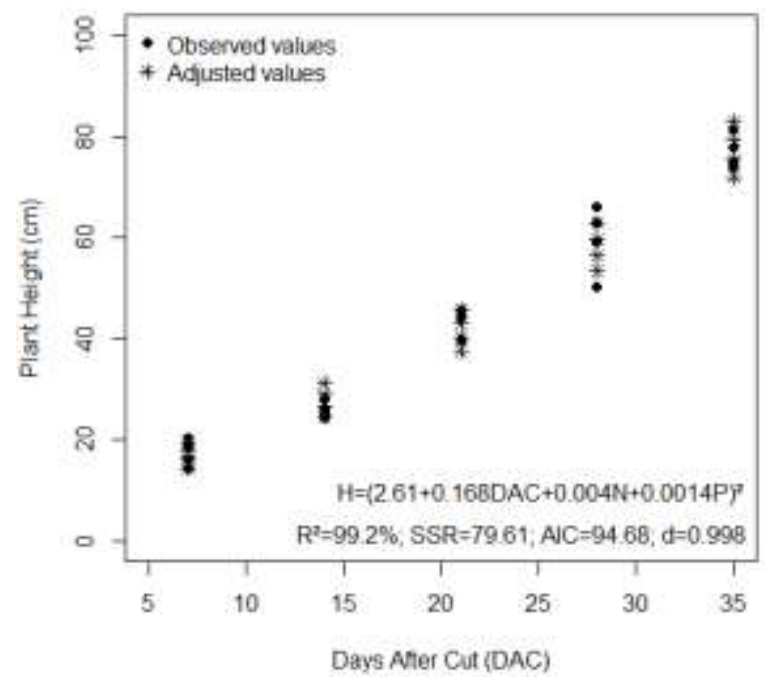

Figure 1 - Urochloa mosambicensis plant height $(\mathrm{H})$ in relation to days after cut and different doses of nitrogen $(\mathrm{N})$ and phosphorus $(\mathrm{P})$. $\mathrm{R}^{2}$ - coefficient of determination; SSR - sum square of residuals; AIC - Akaike's information criteria; d-Willmott index. 
All residues are within the normal range, as they are within the limit of $[-2 ; 2]$ (Figure 2a). No leverage or influence points were found (Figure $2 \mathrm{~b}$ and $2 \mathrm{c}$ ), as all residues are inside the envelope of the gamma distribution (Figure 2d). All these criteria attest to the quality of the model fit.
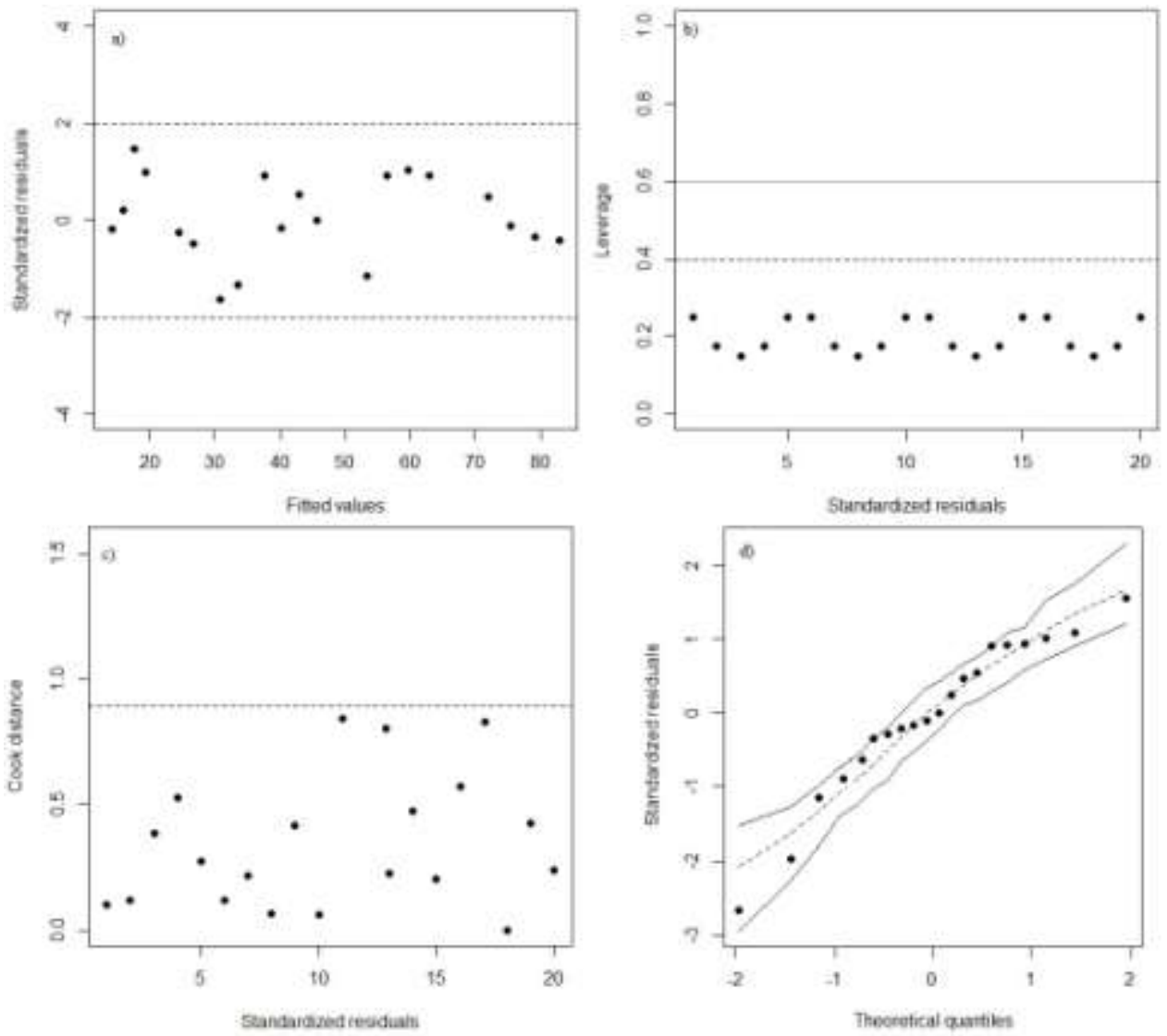

Figure 2 - Residuals analysis of the fitted model to explain Urochloa mosambicensis plant height.

Figure 3 shows the behavior of the $U$. mosambicensis plant height as a function of the day after cutting, evaluating some scenarios of nitrogen and phosphorus application, using the Gamma model.

The smaller plant heights were observed in the absence of nitrogen and phosphorus fertilization in the soil, while the highest plant height is verified when using $500 \mathrm{~kg} \cdot \mathrm{ha}^{-1}$ of nitrogen and $500 \mathrm{~kg} \cdot \mathrm{ha}^{-1}$ phosphorus, a behavior similar to the application of $400 \mathrm{~kg}$. ha ${ }^{-1}$ of nitrogen and $300 \mathrm{~kg} \cdot \mathrm{ha}^{-1}$ of phosphorus. 


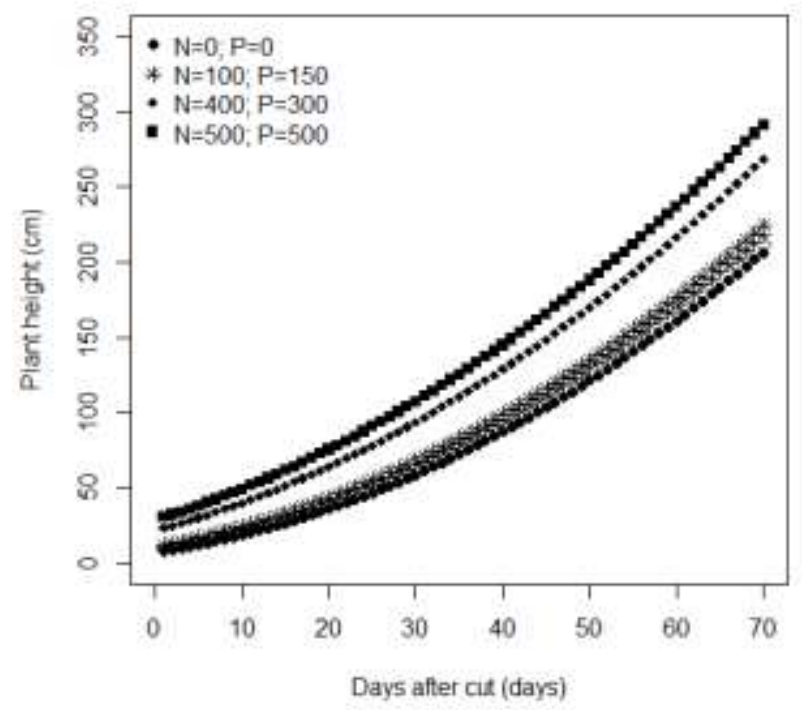

Figure 3 - Prediction of Urochloa mosambicensis plant height using some nitrogen (N) and phosphate (P) fertilization scenarios by the Gamma model.

Grazing management generally uses the physiology of plant growth, synthesized at plant height, as input (pre-grazing) and exit (post-grazing) criteria for grazing. The increase in plant height can be attributed to the fact that nitrogen acts as a main controller of different plant growth and development processes, increases the number of dividing cells and stimulates cell stretching, which provides an increase in biomass through carbon fixation (MARTUSCELLO et al., 2016).

Nitrogen fertilization influenced morphogenesis, plant height and biomass production in massai grass (Panicum maximum) plants (MARTUSCELLO et al., 2015). In turn, phosphate fertilization promoted an increase in the average plant height in Tanzania grass (OLIVEIRA et al., 2007) and urochloa grass (BEZERRA et al., 2019). Increases in plant height in response to nitrogen fertilization have been more evident in cespitosas grasses, in comparison with stoloniferous ones, such as urochloa grass, due to the greater competition for fotoassimilates between stolons and leaves (PEREIRA et al., 2012).

It should be noted that the recommendation of phosphate fertilization will depend, mainly, on the availability of phosphorus in the soil and the degree of solubility of the source used, aiming at minimizing the fixation of the phosphate ion by the soil, and nitrogen fertilization should be recommended as a strategy for the sustainable management of urochloa grass.

It is important to point out that the analysis of the soil in the present rehearsal indicated $40 \mathrm{mg} \mathrm{dm}^{-3}$ of phosphorus $\left(\mathrm{P}_{2} \mathrm{O}_{5}\right)$, a value considered adequate for urochloa 
grass (BEZERRA et al., 2017). However, phosphate fertilization with simple superphosphate $\left(150 \mathrm{~kg} \cdot \mathrm{ha}^{-1}\right)$ in a soil with clay content below the limit of $15 \%$, favored a higher plant height of urochloa grass, regardless of nitrogen, reinforcing the important role of phosphorus in the morphogenesis of this stoloniferous grass. In the early stage of grass development, there is a great demand from plants for phosphorus, due to the intense meristematic activity, caused by the growth of the root system, and phosphorus is essential for cell division, due to its role in the structure of nucleic acids. In addition, the reduced root system restricts the volume of soil explored, limiting the plant's capacity to absorb phosphorus, which is of low mobility in the soil, justifying the initial external demand.

However, the economic viability of fertilization must be taken into account and that high amounts of fertilizers, notably nitrogenous ones, can cause, in the medium and long term, environmental impacts, such as soil acidification, salinization, or even contamination of groundwater. Thus, monitoring of soil fertility should be constant.

\section{Conclusions}

The application of nitrogen and phosphorus increase in Urochloa mosambicensis plant height.

The Urochloa mosambicensis plant height can be explained in function of plant age after cut and the nitrogen and phosphorus fertilization.

The adoption of the Gamma model $H=(2.61+0.168 D A C+0.004 N+0.0014 P)^{2}$ allows to estimate the Urochloa mosambicensis plant height $(\mathrm{H})$, in a non-destructive way, with high precision, speed and low cost, depending of age plant (DAC) and nitrogen (N) and phosphate $(\mathrm{P})$ fertilization in soil.

\section{Acknowledgements}

We would like to thank editors and reviewers for their comments and suggestions.

LEITE, M. L. M. V., LUCENA, L. R. R., BEZERRA, R. C. A., ALMEIDA, M. C. R., SIMÕES, V. J. L. P. Crescimento do capim-urochloa em função da fertilização com nitrogênio e fósforo. Rev. Bras. Biom. Lavras, v.39, n.4, p.492-504, 2021.

- RESUMO: O capim-urochloa (Urochloa mosambicensis) é uma gramínea perene, planta C4, com alta taxa fotossintética e fixação de $\mathrm{CO}_{2}$, persistente ao déficit hídrico e adaptada a uma ampla diversidade de solos e regiões de clima quente. Assim, objetivou-se avaliar o crescimento do capim-urochloa e definir os melhores modelos para estimar a altura de planta em função da adubação nitrogenada e fosfatada. O delineamento experimental foi inteiramente casualizado, em esquema fatorial $2 \times 2$ (presença e ausência de nitrogênio x presença e ausência de fósforo), com quatro repetições. Foi usada uma dose de nitrogênio e fósforo equivalente a $100 \mathrm{~kg}^{\mathrm{ha}} \mathrm{h}^{-1} \mathrm{de}$ $\mathrm{N}$ e $150 \mathrm{~kg} . \mathrm{ha}^{-1}$ de $\mathrm{P}_{2} \mathrm{O}_{5}$, respectivamente. Os modelos: linear, potência, gama e logístico foram utilizados para estimar a altura de planta em função das variáveis explicativas tempo (dias após o plantio) e doses de nitrogênio e fósforo. Os critérios utilizados para determinar os melhores modelos de regressão avaliados foram: alto coeficiente de determinação ajustado, baixo critério 
de informação de Akaike, baixa soma do quadrado de resíduos e alto índice de Willmott. A adoção do modelo Gama apresentou alto poder de explicação para altura de planta do capimcorrente, com alta precisão, rapidez e baixo custo, em função da idade da planta e da adubação nitrogenada e fosfatada.

PALAVRAS-CHAVE: Altura de planta, modelo Gamma, Urochloa mosambicensis.

\section{References}

AKAIKE H. A new look at the statistical model identification. IEEE Transactions on Automatic Control, v.19, n.6, p.716-723, 1974. DOI: 10.1109/TAC.1974.1100705.

ALMEIDA, M. C. R.; LEITE, M. L. M. V.; SÁ JR., E. H.; CRUZ, M. G.; MOURA, G. A.; MOURA, E. A.; SÁ, G. A. S.; LUCENA, L. R. R. Crescimento vegetativo de cultivares de milheto sob diferentes disponibilidades hídricas. Magistra, v.29, n.2, p.161171, 2017.

BEZERRA, F. J. S. M.; LEITE, M. L. M. V.; LUCENA, L. R. R.; PEREIRA, J. S.; SILVA, M. J. A. Características agronômicas de Urochloa mosambicensis em função do nitrogênio e fósforo. Agrarian Academy, v.4, n.7, p.92-102, 2017 . DOI: 10.18677/Agrarian_Academy_2017a9.

BEZERRA, R. C. A.; LEITE, M. L. M. V.; ALMEIDA, M. C. R.; LUCENA, L. R. R.; SIMÕES, V. J. L. P.; BEZERRA, F. J. S. M. Características agronômicas de Urochloa mosambicensis sob diferentes níveis de fósforo e nitrogênio. Magistra, v.30, p.268-276, 2019.

CECATO, U.; SANTOS, G. T.; MACHADO, M. A.; GOMES, L. H.; DAMACENO, J. C.; JOBIM, C. C.; RIBAS, N. P.; MIRA, R. T.; CANO, C. C. P. Avaliação de cultivares do gênero Cynodon com e sem nitrogênio. Acta Scientiarum. Animal Sciences, v.23, n.4, p.781-788, 2001. DOI: 10.4025/actascianimsci.v23i0.2581.

FARINELLI, R.; LEMOS, L. Topdressing nitrogen in maize crop under consolidated conventional and no-tillage systems. Pesquisa Agropecuária Tropical, v.42, n.1, p.63-70, 2012. DOI: $10.1590 / \mathrm{S} 1983-40632012000100009$.

IKEDA, F. S.; VICTORIA FILHO, R.; VILELA, L.; MARCHI, G.; CAVALIERI, S. D.; SILVA, A. A. Emergência e crescimento inicial de cultivares de Urochloa em diferentes profundidades de semeadura. Planta Daninha, v.31, n.1, p.71-78, 2013. DOI: $10.1590 / \mathrm{S} 0100-83582013000100008$

KHAN, S.; HUSSAIN, A. Effects of nitrogen fertilizer on forage yield of buffel grass. Sarhad Journal of Agriculture, v.20, n.3, p.425-428, 2004.

LEITE, M. L. M. V.; LUCENA, L. R. R.; SÁ JÚNIOR, E. H.; CRUZ, M. G. Estimativa da área foliar em Urochloa mosambicensis por dimensões lineares. Revista Agropecuária Técnica, v.38, n.1, p.9-16, 2017. DOI: 10.25066/agrotec.v38i1.32041

LEITE, M. L. M. V.; LUCENA, L. R. R.; CRUZ, M. G.; SÁ JR., E. H.; SIMÕES, V. J. L. P. Leaf area estimate of Pennisetum glaucum by linear dimensions. Acta Scientiarum Animal Science, v.41, p.e42808, 2019. DOI: 10.4025/actascianimsci.v41i1.42808 
LISKA, G. R.; SILVEIRA, E. C.; REIS, P. R.; CIRILlO, M. A.; GONZALEZ, G. G. H. Selecting a binomial regression model on the predation rate of Euseius concordis (Chant, 1959). Coffee Science, v.10, n.1, p.113-121, 2015. DOI: 10.25186/cs.v10i1.786.

LUCENA, L. R. R.; LEITE, M. L. M. V.; PEREIRA, J. S.; CAVALCANTE, A. B. Ajuste de curvas de crescimento do comprimento do cladódio de Nopalea cochenillifera. Biomatemática, v.26, p.39-52, 2016.

LUCENA, L. R. R.; LEITE, M. L. M. V.; CRUZ, M. G.; SÁ JÚNIOR, E. H. Estimativa da área foliar em Urochloa mosambicensis por dimensões foliares e imagens digitais. Archivos de Zootecnia. V.64, n.259, p.408-413, 2018. DOI: 10.21071/az.v67i259.3798.

MANGUEIRA, R. A. F.; SAVIAN, T. V.; MUNIZ, J. A.; SERMARINI, R. A.; CROSARIOL NETTO, J. O. Modelo logístico considerando diferentes distribuições para os erros aplicados a dados de altura do milho. Revista Brasileira de Biometria, v.34, n.2, p.317-333, 2016.

MARTINS, A. O.; CAMPOSTRINI, E.; MAGALHÃES, P. C.; GUIMARÃES, L. J. M.; DURÃES, F. O. M.; MARRIEL, I. E.; TORRES NETTO, A. Nitrogen-use efficiency of maize genotypes in contrasting environments. Crop Breeding and Applied Biotechnology, v.8, n.4, p.291-298, 2008. DOI: 10.12702/1984-7033.v08n04a06.

MARTUSCEllo, J. A.; SIlVA, L. P.; CUNHA, D. N. F. V.; BATISTA, A. C. S.; BRAZ, T. G. S.; FERREIRA, P. S. Adubação nitrogenada em capim-massai: morfogênese e produção. Ciência Animal Brasileira, v.16, n.1, p.1-13, 2015. DOI: 10.1590/108968916 i1 18730

MARTUSCELlO, J. A.; MAJEROWICZ, N.; CUNHA, D. N. F. V.; AMORIM, P. L.; BRAZ, T. G. S. Características produtivas e fisiológicas de capim-elefante submetido à adubação nitrogenada. Archivos de Zootecnia, v.65, n.252, p.565-570, 2016. DOI: 10.21071/az.v65i252.1927.

MATA, J. F.; ERASMO, E. A. L.; SIEBENEICHLER, S. C.; SARAIVA, A. S.; GONÇALVES, R. C. Análise de crescimento da Brachiária em diferentes densidades e épocas de semeadura em consorcio com a cultura da soja. Revista Brasileira de Tecnologia Aplicada nas Ciências Agrárias, v.4, n.3, p.7-30, 2011. DOI: 10.5777/part.v4i3.1494.

MENEZES, J. F. S.; BERTI, M. P. S.; VIEIRA JUNIOR, V. D.; BERTI, C. L. F. Extraction and export of nitrogen, phosphorus and potassium by maize fertilized with pig slurry. Revista de Agricultura Neotropical, v.5, n.3, p.55-59, 2018. DOI: 10.32404/rean.v5i3.1645.

OLIVEIRA, A. B.; PIRES, A. J. V.; MATOS NETO, U.; CARVALHO, G. G. P.; VELOSO, C. M.; SILVA, F. F. Morfogênese do capim-tanzânia submetido a adubações e intensidades de corte. Revista Brasileira de Zootecnia, v.36, n.4, p.1006-1013, 2007. DOI: $10.1590 / \mathrm{S} 1516-35982007000500004$.

PEREIRA, O. G.; ROVETTA, R.; RIBEIRO, K. G.; SANTOS, M. E. R.; FONSECA, D. M.; CECON, P. R. Crescimento do capim-tifton 85 sob doses de nitrogênio e alturas de corte. Revista Brasileira de Zootecnia, v.41, n.1, p.30-35, 2012. DOI: 10.1590/S151635982012000100005 
R CORE TEAM. $R$ : a language and environment for statistical computing. Vienna: $\mathrm{R}$ Foundation for Statistical Computing, 2021.

SÁ JÚNIOR, E. H.; CRUZ, M. G.; LEITE, M. L. M. V.; LUCENA, L. R. R. Características agronômicas de capim-corrente (Urochloa mosambicensis) adubado com esterco suíno e submetido a duas alturas de corte. Ciência Agrícola, v.16, n.1, p.1-9, 2018. DOI: $10.28998 /$ rca.v16i1.3303.

SANTOS, A. L. P.; MOREIRA, G. R.; BRITO, C. C. R.; SILVA, F. G.; COSTA, M. L. L.; PIMENTEL, P. G.; FILHO, M. C.; MIZUBUTI, I. Y. Method to generate growth and degrowth models obtained from differential equations applied to agrarian sciences. Semina: Ciências Agrárias, v.39, n.6, p.2659-2672, 2018. DOI: 10.5433/16790359.2018v39n6p2659

SILVA, E. M.; FURTADO, T. D. R.; FERNANDES, J. G.; CIRILLO, M. A.; MUNIZ, J. A. Leaf count overdispersion in coffee seedlings. Ciência Rural, v.49, n.4, p.e20180786, 2019. DOI: $10.1590 / 0103-8478 \mathrm{cr} 20180786$

WILLMOTT, C. J. On the validation of models. Physical Geography, v.2, n.2, p.184-194, 1981. DOI: $10.1080 / 02723646.1981 .10642213$.

Received on 04.08.2020

Approved after revised on 21.05.2021 